\title{
The Jewish communities of Safed and Jerusalem during
}

\author{
the fourteenth century*
}

\section{MICHAEL EHRLICH}

\begin{abstract}
In this article I suggest that, although many Jews perished during the wars between the Mamluks and the Franks during the thirteenth century's second half, and others migrated to different Jewish communities in the Middle East and Europe, some Jews migrated to Safed, Jerusalem, and perhaps to Gaza as well. A significant number of the Jews who lived in Safed and Jerusalem during the early decades of the fourteenth century were of a Western European origin but were not newcomers from Europe. I suggest that some of these were Jews who previously lived in Acre and Tyre and migrated to Safed and Jerusalem either shortly before the Latin Kingdom of Jerusalem got its coup de grâce, or afterwards.
\end{abstract}

\section{Introduction}

The two most important Jewish communities of the Latin Kingdom of Jerusalem during the thirteenth century were Acre and Tyre. ${ }^{1}$ These communities ceased to exist following the Mamluk conquest in I29I, and their members were killed, captured, or emigrated to other Jewish communities in Europe or the Middle East. ${ }^{2}$

I am suggesting that, although many Jews perished during the wars between the Mamluks and the Franks during the thirteenth century's second half, and others migrated to different Jewish communities in the Middle East and Europe, some Jews migrated to Safed, Jerusalem, and perhaps to Gaza as well. A significant number of the Jews who lived in Safed and Jerusalem during the early decades of the fourteenth century were of a Western European origin but were not newcomers from Europe. I suggest that some of these were Jews who previously lived in Acre and Tyre and migrated to Safed and Jerusalem either shortly before the Latin Kingdom of Jerusalem got its coup de grâce, or afterwards. Historical sources.

*I would like to thank Professor Reuven Amitai from the Hebrew University in Jerusalem for his comments and advices.

${ }^{1} \mathrm{~J}$. Prawer, The History of the Jews in the Latin Kingdom of Jerusalem (Oxford, I988), pp. I I7-I2 I.

${ }^{2}$ Ibid., pp. 29I-293. This is an Open Access article, distributed under the terms of the Creative Commons Attribution licence (http://creativecommons. $\mathrm{org} /$ licenses/by/4.0/), which permits unrestricted re-use, distribution, and reproduction in any medium, provided the original work is properly cited.

doi:I0.10I7/S1356186319000506 
The period between the fall of the Latin Kingdom of Jerusalem in I29I and the midfourteenth century is poorly documented. Jewish immigrants and pilgrims were scarce during this period and Christian and Muslim writers barely mentioned Jews. As a result, the knowledge about the Jewish communities during this period is limited.

The most important Jewish book composed in the Holy Land during this period is Caftor va- Ferach, by Rabbi Moses b. Isaac, usually known by his pseudonym Estori ha-Parchi. ${ }^{3} \mathrm{He}$ wrote his book between I3I4 and I322, when he lived first in Jerusalem and later in Bethsan. ${ }^{4}$ There is no information about Estori ha-Parchi's life after he wrote his book. He was probably an immigrant, because it seems likely that if he did not return after seven years in the Holy Land, he intended to remain there. Caftor va-Ferach is a book dedicated to the Jewish laws related to the Land of Israel. In this book, the author also described the Holy Land but did not describe contemporary Jewish communities in detail.

Another source is "The Paths of the Holy Land", a book written by R. Isaac Chelo, a Jewish pilgrim from Aragon, in I333. An annotated French translation of this book was published by Carmoly in Brussels in I $847 .{ }^{5}$ Unfortunately, the pages of the manuscript that Carmoly allegedly translated disappeared, and only its first nine lines have survived. ${ }^{6}$ Carmoly's translation includes many references to issues of kabbalah, which lead Gershom Scholem to assert in 1934 that the kabbalic material included in this book was added by a copyist, most probably Carmoly himself. Scholem did not deal with the abundant geographic material included in Chelo's presumed oeuvre, because he was not a specialist in the history of travels, pilgrimage, and related disciplines. ${ }^{7}$ Most of Gershom Scholem's observations about the intrusion of later kabbalic material are still irrefutable.

In I936, Mordechai Ish-Shalom scrutinised Chelo's geographic material and concluded that it is a mishmash of reused material and Carmoly's inventions. ${ }^{8}$ Yet, in an earlier study I demonstrated that, despite Ish-Shalom's comments, most of the geographic material included in Carmoly's translation faithfully describes the fourteenth century Holy Land. Therefore, the kabbalic material was probably intruded separate to Chelo's geographical description. These additions are clearly discernible, and therefore there is no reason not to use Chelo's geographical information. ${ }^{9}$

The Cairo Genizah also includes useful, though limited, information relevant to this research. References to Jewish personalities in Safed and Jerusalem are scattered in contemporary Jewish literature.

Jews were sometimes mentioned by contemporary Christian pilgrims and Muslim sources as well.

${ }^{3}$ A. M. Luncz (ed.), Caftor va-Ferach par Estori ha-Parchi, [in Hebrew], 2 vols. (Jerusalem, I897-1899).

${ }^{4}$ M. McVaugh, L. Ferre, The Tabula Antidotarii of Amergand Blaise (Philadelphia, 2000), pp. I0-I4; B. Zolty, "Estori Ha-Parhi, Caftor wa-ferach", PhD Thesis (Paris, 2003), p. 35; A. Schwartz, "Ashtori HaParhi: The Man and His Literary Works" [in Hebrew] PhD Thesis, Ariel University 20I9, pp. 3I-36.

${ }^{5}$ E. Carmoly (ed. \& Transl), Itinéraires de la Terre Sainte des XIIIe, XIVe, XVe, XVIe et XVIIe siècle (Bruxelles, I847), pp: 2 I9-320.

${ }^{6}$ Frankfurt a. M. Universitätsbibliothek Oct. 47.

${ }^{7}$ G. Shalom, "S. Shviley Yerushalem Hameyuhas le Rabbi Izhaq Chelo - Mezuyaf", [in Hebrew], Zion: Me'asef ha-Hevra ha-Erets-Yisre'elit le-Historyah ve-Etnografyah, VI (I934), pp. 39-53.

${ }^{8}$ M. Ish-Shalom, “On 'Shevile Dirushalaim' of R. Isaac b. R. Joseph Chelo”, [in Hebrew], Tarbiz, VI (I935), pp. I97-209.

${ }^{9}$ M. Ehrlich, "Is the Book 'The Paths of Jerusalem (Shviley DeYerushalem)', Attributed to Rabbi Issac Chelo a Forgery?”, [in Hebrew], Jerusalem \& Eretz-Israel, VI (2008), pp. 59-88. 


\section{Previous Studies}

In I988, Joshua Prawer published a book about the history of the Jews in the Latin Kingdom of Jerusalem. That book is still the most comprehensive study about the Jews in the Crusader Kingdom. ${ }^{10}$ Prawer dedicated a long chapter to the Jews in the Latin Kingdom during the thirteenth century, in which he described in detail the rise and fall of the Crusader Kingdom's Jewish communities, and especially the Jewish community of Acre. ${ }^{11}$ However, Prawer focused on the Jewish communities of Acre and Tyre, and barely described inland communities such as those of Jerusalem and Safed.

In I954, Joseph Braslavsky included in his book two short articles about the Ashkenazi immigration to the Land of Israel and the history of the Jewish community in fourteenth century Gaza. ${ }^{12}$ I shall not deal with the article about Gaza, because it is based on a pilgrim description from $1395 .{ }^{13} \mathrm{I}$ do not preclude the possibility that some Jews who lived in Gaza in 1395 stemmed from families who previously lived in Frankish Tyre and Acre; but since the short reference from I 395 is the first to mention Jews in Mamluk Gaza, further evidence is required to support this claim.

Braslavsky did refer to Western European Jews who lived in Jerusalem and Safed during the fourteenth century and presumed that they immigrated during that century. He wondered about the circumstances that provoked the Ashkenazi Jews' emigration to the Holy Land during this period. He also focused on a short paragraph in Jacques of Verona's book in which Jews are praised as expert guides, concluding that Jews were able to easily communicate with European pilgrims. ${ }^{14}$

In I996, Sylvia Schein published a short article about the Jews of the Latin Kingdom of Jerusalem. ${ }^{15}$ Schein focused on the status of the Jewish community in the Crusaders' kingdom, as a Western European Jewish community which developed in the East, and its contacts with both European and Eastern Jewish centres. Schein did not deal with this community's fate once the Franks were defeated and left the Middle Eastern scene.

In 1988 Elchanan Reiner wrote a $\mathrm{PhD}$ thesis about Medieval Jewish pilgrimage and settlement to the Land of Israel. ${ }^{16}$ Yet, Reiner did not suggest that Jews migrated internally from the Frankish-dominated centres to the Muslim areas. In an earlier article published in I984, he opined that the Ashkenazi ownership of the Ashkenazi courtyard in Jerusalem had probably already begun in the fourteenth century. ${ }^{17}$ Later, Reiner changed his mind and suggested that this area in Jerusalem became Ashkenazi property no earlier than the fifteenth century. ${ }^{18}$

\footnotetext{
${ }^{10}$ Prawer, History of the Jews.

${ }^{11}$ Ibid., pp. $25 \mathrm{I}-29 \mathrm{I}$.

${ }^{12}$ J. Braslavsky, Studies in Our Country: Its Past and Remains, [in Hebrew] (Tel-Aviv, I954), pp. I29-I36.

${ }^{13}$ Ibid., pp. $135-136$.

${ }^{14}$ Ibid., pp. I29-1 32 .

${ }^{15}$ S. Schein, "Between East and West: the Jews in the Latin Kingdom of Jerusalem I099-I29I", in East and West in the Crusader States, eds. K. Ciggaar, A. Davids, and H. Teule, (Leuven, I996), i, pp. $3 \mathrm{I}-38$.

${ }^{16}$ E. Reiner, "Pilgrims and Pilgrimage to Eretz-Israel I099-I5I7", [in Hebrew], PhD Thesis, The Hebrew University of Jerusalem I988.

${ }^{17}$ E. Reiner, "Between Ashkenaz and Jerusalem", Shalem, IV (I984), p. 59, n. I I9.

${ }^{18}$ E. Reiner, "The Courtyard of the Ashkenazim in Jerusalem: Early Days", in The Hurva Synagogue: Six Centuries of Jewish Settlement in Jerusalem, (eds.) R. Gafni, A. Morgenstern, and D. M. Cassuto, (Jerusalem, 201о), pp. I I -44 .
} 
Alexandra Cuffel published an extensive article on the European Jewish emigration to Egypt and Palestine during the medieval period. This article dealt with possible motives behind these emigrations, and with the obstacles that emigrants met in the East, but did not deal with the establishment of European Jewish communities in Safed or in Jerusalem. ${ }^{19}$ Israel Yuval wrote about Jewish immigration of Ashkenazi origin to the Holy Land during the fourteenth century's second half, after the 'Black Death'. Yuval acknowledged that there were Jews of Western-European origin in Jerusalem during the century's first half, but they were few and unorganised unlike those who immigrated during the second half of the century. Furthermore, Yuval suggested that Ashkenazi Jews who lived in Jerusalem during the century's first half immigrated to the Holy Land during the fourteenth century, and that during the century's second half this immigration intensified. ${ }^{20}$

\section{Jewish communities in the Holy Land before the Mamluk period}

Around II70, the famous Jewish traveller Benjamin of Tudela described various Jewish communities he visited in the Holy Land. Benjamin of Tudela met Jews mainly in coastal cities: 500 Jews in Tyre, 200 in Acre and Caesarea, and 340 in Ascalon. ${ }^{21}$ In inland regions, he described communities of 50 Jews (probably 50 Jewish families) in Tiberias and in the village of 'Alma, 4 in Jerusalem, and less than 5 Jews in a number of other settlements. ${ }^{22}$

Of the coastal communities, only Acre's and Tyre's Jewish communities continued to exist and even expanded during the thirteenth century. ${ }^{23}$ The Jewish community of Caesarea was not mentioned during the thirteenth century, and the city of Ascalon was destroyed by Saladin during the Third Crusade (I I92). ${ }^{24}$

\section{Safed's Jewish Community until the fourteenth century}

The first record about Safed after the Roman period is an eleventh century Genizah document which referred to a Jew from Safed who was a shop owner in Tiberias' market. ${ }^{25}$ This documentation indicates that during the eleventh century there was at least one Jew in Safed. It does not indicate the percentage of Jews in Safed's entire population. Safed became a Frankish settlement during the twelfth century, but Jews from Safed were not mentioned in twelfth century documents. ${ }^{26}$

\footnotetext{
${ }^{19}$ A. Cuffel, "Call and Response: European Jewish Emigration to Egypt and Palestine in the Middle Ages", Jewish Quarterly Review, XC (I999), pp. 6I-IO2.

${ }^{20}$ I. Yuval, "Alms from Nuremberg to Jerusalem (I375-I392)", [in Hebrew], Zion, XLVI (I98I), pp. I82-I97.

${ }^{21}$ M. N. Adler, The Itinerary of Rabbi Benjamin of Tudela (London: Henry Frowde, 1907), pp.I 8-28.

${ }^{22}$ Ibid., pp. 20-27. According to another manuscript of Benjamin of Tudela's book there were 200 Jews in Jerusalem. This number is unlikely, because such a number implies the existence of a community, which Benjamin, who usually described communities in detail, did not do so in this case.

${ }^{23}$ Prawer, History of the Jews, pp. 254-29I.

${ }^{24}$ M. Sharon, Corpus Inscriptionum Arabicum Palaestinae, 6 vols. (Leiden, I997-20I7), I, pp. I38-139.

${ }^{25}$ M. Gil, Palestine during the First Muslim Period, [in Hebrew], 3 vols. (Tel-Aviv, I983), ii, pp. 447-448, no. 245.

${ }^{26} \mathrm{H}$. Barbé, "Le château de Safed et son territoire a l'époque des croisades", PhD Thesis, The Hebrew University of Jerusalem 20Io, pp. 263-269; idem, "Safed Castle and its Territory: Frankish Settlement and Colonisation during the Crusader Period", in Crusader Landscapes in the Medieval Levant, (eds.) M. Sinibadi et al. (Cardiff: University of Wales Press, 20I6), pp. 63-67.
} 
Nevertheless, during the thirteenth century Safed was likely an important, possibly the most important, Jewish community in the Galilee.

During the I2 Ios, two Jewish travellers, Samuel b. Samson and Menachem of Hebron described different Jewish communities in the Holy Land. Samuel b. Samson described the visit in I209 -I 2 IO of R. Jonathan of Lunel in Jerusalem and then accompanied the Exilarch during his visit to some inland Jewish communities, including Safed. ${ }^{27}$ Samuel b. Samson did not describe the Jewish community of Tiberias, but he did describe some rural Jewish communities in the Upper Galilee. The most important community in the area was apparently Safed, from which the Exilarch, accompanied by Samuel b. Samson and his colleagues, commuted to visit the region's communities and shrines. Safed was also the place where they stayed for Shabbat. ${ }^{28}$ Presumably, Safed emerged as an alternative centre to the declining Jewish community of Tiberias. Tiberias became secondary to Safed when the Ayyubids established the Iqta ' of Safed and Tiberias. ${ }^{29}$ Subsequently, Tiberias' Jewish community faded away during the thirteenth century.

Menachem of Hebron described Jewish communities in Tiberias and Bāniyās shortly after Samuel b. Samson's pilgrimage (ca. I2 I5). ${ }^{30}$ Menachem was the last visitor who described these two Jewish communities. Tiberias's Jewish community was re-established during the Ottoman period, whereas the Bāniyās community was never re-established. He also described Safed and other localities in the Galilee region but did not mention Jews in Safed. Unlike Samuel b. Samson, Menachem of Hebron mentioned the coastal Frankish sites of Caesarea, Haifa, Acre, Tyre, Sidon, and Beirut. ${ }^{31}$ Yet he did not mention the contemporary Jewish communities which flourished in some of these localities, such as Tyre and Acre, where large Jewish communities existed throughout the thirteenth century. ${ }^{32}$

According to one version of R. Judah al-Harīzî̀s book Tahkemoni (I I I6), he met the head of the Yeshiva of the Land of Israel in Safed. ${ }^{33}$ Nevertheless, this reference only exists in one version of al-Harīzì's book, and there is no further evidence of rabbis who lived in Safed before the I280s.

The description of Benoit d'Alignan, bishop of Marseilles, who initiated the construction of the Templar Castle of Safed during the I24Os, includes the sentence: "the bishop pitched his tents between the site of the synagogue of the Jews and the mosque of the Saracens". ${ }^{34}$ During the last decade of the Latin Kingdom of Jerusalem, the leaders of Safed's Jewish community excommunicated those who argued that Maimonides's writings include heresy. The excommunication document begins with the phrase: "We the community who lives in Safed kahal Sefat" suggesting that Safed had an organised Jewish community. Unfortunately, the only indication as to the origins of Safed's rabbis is that one of them was the son of a

\footnotetext{
${ }^{27}$ E. N. Adler, Jewish Travellers, $2^{\text {nd }}$ edition, (New York, I966), pp. I03-I04; M. Ehrlich, "Les deux periples de Samuel b. Samson en Terre Sainte", Journal Asiatique (forthcoming); idem, "Bene Ma'arava”, Pe 'amim (forthcoming, in Hebrew).

${ }^{28}$ Ibid., pp. I07-109.

${ }^{29}$ R. S. Humphreys, From Saladin to the Mongols (Albany, I977), p. I42.

${ }^{30}$ A. M. Luncz (ed.), HaMe amer III (I9I9), pp. 40-4I.

${ }^{31}$ Ibid., p. 38 .

${ }^{32}$ Ibid., pp. $4 \mathrm{I}-42$.

${ }^{33} \mathrm{~J}$. Yahalom and N. Katsumata (eds.), TahKemoni, [in Hebrew] (Jerusalem, 20I0), p. 452.

${ }^{34}$ R. B. C. Huygens (ed.), De constructione castri Saphet (Amsterdam, I98I), p. 38; H. Kennedy, Crusader Castles (Cambridge, I994), p. I94.
} 
convert. ${ }^{35}$ Since both Muslims and Christians alike did not tolerate apostasy, this rabbi or his father should have arrived in Safed from a Christian land. Namely, the rabbi's father was either a Christian who converted and immigrated to a Muslim land, or a Muslim who converted in a Christian land, and then immigrated to a Muslim land.

Another Jew from Safed was the physician Asad al-Yahūdī, who lived at the end of the thirteenth century and the fourteenth century's first half. ${ }^{36}$ Although Asad might have converted to Islam, he was probably the product of a vibrant community which emerged in Safed after the Mamluk conquest.

Presumably, the Jewish community of Safed developed during the thirteenth century, especially after the establishment of the Templar Castle during the I240s, and even more after the Mamluk conquest of Safed.

\section{Jerusalem during the early Mamluk period}

In I267, R. Moses b. Nahman, commonly known as Nachmanides, who fled from Aragon, described the situation of Jerusalem in a well-known letter to his son:

But what shall I say to you concerning the country? Great is the solitude and great the devastation, and, to put it briefly, the more sacred the places, the greater their desolation. Jerusalem is more desolate than the rest of the country: Judea more than Galilee... It has about 2,00o inhabitants, about 300 Christians live there who escaped from the sword of the Sultan. There are no Jews. For, after the arrival of the Tatars, some fled while others died by their sword. There are only two brothers, dyers by trade, who have to buy their ingredients from the government. There the Ten Men meet, and on Sabbaths they hold the service at their home. But we encouraged them, and we succeeded in finding a vacant house, built on pillars of marble with a beautiful arch. That we took for a synagogue. For the town is without a ruler, so that whoever desires to take possession of the ruins can do so... ${ }^{37}$

Nachmanides' description indicates that a Jewish community did not exist in Jerusalem until I267. In I286, five years before the conquest of Acre by the Mamluks and the abolition of the Frankish presence in the East, R. Meir of Rothenburg made an unsuccessful attempt to immigrate to the Holy Land. Abraham Grossman suggested that R. Meir's destination was Jerusalem and not Acre, where earlier Jewish immigrants usually settled, ${ }^{38}$ because by 286 the upcoming eradication of the Latin Kingdom of Jerusalem was already evident. Unfortunately for R. Meir, he was arrested while on his way to an Italian port by the envoys of Emperor Rudolf I of Habsburg, who probably hoped to receive a high ransom for R. Meir's release. According to contemporary Jewish hearsays, R. Meir himself refused to be ransomed and died in prison. ${ }^{39}$ It is unclear how many Jews, if any, of R. Meir's entourage arrived in the Holy Land before R. Meir of Rothenburg's arrest or following it.

${ }^{35}$ Prawer, The History of the Jews, pp. 282-286; Sh. L. Goldenberg (ed.), Kerem Chemed, III (I 838), pp. I72-I 73.

${ }^{36}$ A. Mazor, "Jewish Court Physicians in the Mamluk Sultanate", Medieval Encounters, XX (20I4), pp. 54-60.

${ }^{37}$ F. Kobler, Letters of Jews through the Ages (London, I952), I, p. 226.

${ }^{38}$ A. Grossman, "Meir b. Baruch of Rothenburg and Eretz-Israel", [in Hebrew], Cathedra, LXXXIV (I997), pp. $77-8$ o.

${ }^{39}$ S. Emanuel, “Did Rabbi Meir of Rothenburg Refuse Redemption from Prison?”, [in Hebrew], Netuim, XIX (2014), pp. I55-I69; I. A. Agus, Rabbi Meir of Rothenburg (Philadelphia, I947), I, pp. I25-I33; Joseph I. Lifshitz, Rabbi Meir of Rothenburg and the Foundation of Jewish Political Thought (New York, 20I6), pp. 44-46. 


\section{The Jewish community of Safed during the fourteenth century}

The fall of the Latin Kingdom of Jerusalem precipitated a papal prohibition on sailing between Europe and the Holy Land. ${ }^{40}$ Nevertheless, those who wanted to travel, or to immigrate, found ways to execute their plans. Presumably this prohibition made travel more difficult and expensive than it was prior to the prohibition but did not stop it. For example, R. Shem-Tov b. Gaon arrived in Safed around I3 I $5 .{ }^{41}$

Around I 3 I 5, Estori ha-Parchi described a large Jewish community in Safed. Estori wrote that he was asked by the local community in which of the Israelite tribes' territories was Safed located. ${ }^{42}$ Such a question seems to indicate that Safed was a newly established community, not a community which had existed in the Holy Land for many centuries and had its own traditions.

Isaac Chelo, whose description (I333) has been deemed a forgery by I930s scholars, described a vivid Jewish community in Safed. According to Chelo, this community was composed of Jews from all over the Jewish world. He also wrote that the late R. Shem-Tov b. Gaon from Soria (Castile) composed many of his books in Safed. ${ }^{43}$

Gershom Scholem disputed the veracity of Chelo's descriptions, arguing that there was no evidence that Rabbi Shem-Tov was dead by I333, nor evidence that he has been described as a former resident of Soria during his stay in the Holy Land. Furthermore, he postulated that the suggestion that the Jewish community of Safed was composed of Jews from all over the world does not fit the fourteenth century but rather the period of the great Jewish expulsion from Spain (I 492). These three points led Scholem to suggest that Chelo's presumed description of Safed was an invention made by a later copyist. ${ }^{44}$ Scholem was unaware of a fourteenth-century Cairo Genizah document which clearly supports Chelo's alleged description and refutes two of Scholem's three arguments: ${ }^{45}$

In 'Amuqa is the Tomb of R. Jonathan b. 'Uzi'el, the author of the Bible's Jerusalemite translation. Atop of the tomb there is a new and beautiful ashlar building. It was built thanks to the efforts of R. Shem-Tov b. Gaon of blessed memory, the Spaniard from the city of Soria together with the distinguished foreigners who lived in Safed during this period. Because there were at that place dignitaries from Barcelona, and people from Spain, France, Ashkenaz, and Brittany. Alas, now because of our sins, only a few of many survived. ${ }^{46}$

This Genizah document clearly suggests that R. Shem-Tov was called "R. Shem-Tov from Soria", not only in the Iberian Peninsula, but also in the East. Furthermore, it confirms that during the fourteenth century, Safed's Jewish community was composed of Jews of various origins, exactly as described by Chelo. Although there is no evidence that R. Shem-Tov died before $\mathrm{I} 333$, there is also no evidence that he was alive then. Therefore, as far as the description of Safed's Jewish community during the fourteenth century's first half is p. 83 .

${ }^{40}$ S. Schein, Fidelis Crucis, The Papacy, the West, and the Recovery of the Holy Land 1274-1314 (Oxford, I99I),

${ }^{41}$ D. S. Löwinger, "Rabbi Shem-Tov b. Abraham Ga'on”, [in Hebrew], Sefunot, VII (I923), pp. 9-Io.

${ }^{42}$ Luncz, Caftor va- Ferach, i, pp. $283-286$.

${ }^{43}$ Carmoly, Itinéraires, p. $26 \mathrm{I}$.

${ }^{44}$ Shalom, 'S. Shviley', pp. 49-52.

${ }^{45}$ Zvi Ilan, Tombs of the Righteous in the Land of Israel, [in Hebrew] (Jerusalem, I997), p. 85.

${ }^{46}$ Ibid., p. 94 . 
concerned, Chelo's description is reliable because it is strongly supported by independent evidence. Moreover, according to one of the versions of Ludolph of Suchem who described the Holy Land during the years I336-I34I met a Jewish couple from Westphalia in a place he called Japhet, near a large castle between the Sea of Galilee and the Jordan River's sources. ${ }^{47}$ Ludolph's Japhet was probably Safed. Having met a Jew from Westphalia there provides further support to the cosmopolitan character of the Jewish community of Safed during the fourteenth century's first half.

Presumably, Scholem's scepticism about Chelo's description of Safed stemmed from his thinking that during that period Jewish immigration to the Holy Land declined. He was also unaware of the Genizah source which referred to R. Shem-Tov in the same title as Chelo and described Safed as a cosmopolitan community during the fourteenth century's first half.

The community's profile suggests that it was the result of Jewish migration, not of natural increase. The developing regional centre probably attracted newcomers more than other sites. Nevertheless, it does not provide an explanation as to the migration of Western-Europeans to a remote site without important holy traditions, during a period when traveling to the Holy Land became exceptionally expensive and difficult. Therefore, I suggest that some of the European Jews who lived in Safed during the fourteenth century's first half were immigrants from nearby communities, such as Frankish Acre and Tyre.

\section{The Jewish community of Jerusalem during the fourteenth century}

The ethnic profile of Jerusalem's Jewish community during the fourteenth century's first half seems similar to Safed's contemporary community. Nachmanides described Jerusalem in I 267 as being without a Jewish community. Nachmanides' remark that, on Saturdays, there were ten Jews in Jerusalem indicates that although Jews did not live in Jerusalem, some Jews lived nearby.

Yet, during the fourteenth century, a Jewish community emerged in Jerusalem. Unlike Safed, Jerusalem lacked an indigenous Jewish community. Estori ha-Parchi, who lived in Jerusalem before moving to Bethsan, described a synagogue and a Jewish neighbourhood in Jerusalem, but he did not provide details about the community members' origin. In Jerusalem Estori ha-Parchi met R. Baruch, who was a disciple of R. Meir of Ashkenaz, probably R. Meir of Rothenburg. ${ }^{48}$ Estori also confirmed that he decided to live in Bethsan, an unexpected choice for a fourteenth-century Jewish scholar, to avoid the controversy that took place during his stay in large cities, probably in Jerusalem. Luncz suggested that Estori was referring to the controversy about Maimonides' writings. ${ }^{49}$ Estori did not specify the controversy that provoked his leaving of Jerusalem, but his statement indicates that when he arrived in Jerusalem there was a vibrant Jewish community there. If Luncz is correct, the controversy was a fourteenth century continuation of the polemic which emerged in Acre in $1285 .^{50}$

\footnotetext{
${ }^{47}$ F. Deycks (ed.), Ludolphi de Itinere Terrae Sanctae Liber (Stuttgart, I 85 I), p. 97.

${ }^{48}$ Luncz, Caftor va- Ferach, ii, p. 529.

${ }^{49}$ Ibid., i, p. 4 .

${ }^{50}$ Prawer, History of the Jews, pp. 282-29I.
} 
Some Western Christian pilgrims indicated that they were guided by Jews during their pilgrimage to Jerusalem. Wilhelm from Boldensele who visited the Holy Land in I 333 indicated that during his visit to Jerusalem and its vicinity he was guided by a Jew of German origin. ${ }^{51}$ Jacques of Verona who arrived two years later claimed that Jewish guides were well acquainted with local traditions. ${ }^{52}$ Jerusalem was one of the main Jewish communities in the Holy Land during the fourteenth century; therefore, although Jacques of Verona did not indicate where he met Jewish guides, some of them probably lived in Jerusalem. As Jacques of Verona indicated, Jewish guides had a reputation of being well acquainted with local traditions. I suggest that the peculiar choice of Jewish guides for Christian pilgrims stemmed from their ability to communicate in European languages, an ability which neither Muslim nor local Christian guides possessed. The acquaintance in local traditions usually characterises well-established residents, rather than newcomers. Yet, it is impossible to preclude the possibility that people who emigrated from Western Europe became experts in the Holy Land's roads, holy sites, and sacred traditions.

R. Isaac Chelo described Jerusalem's Jewish community as a cosmopolitan community whose leaders were R. Joseph and R. Chaim from France. ${ }^{53}$ Two rabbis from Jerusalem, Haim HaTsarfati (from France) and Joseph from Marseilles, were mentioned in an undated response written by R. Nissim of Gerona (I 3 I 5-I 376). ${ }^{54}$ The issue addressed in this long response was the possible breach of a mutual oath made by two individuals to emigrate to the East. R. Nissim's answer that the breaking of the oath was acceptable was based primarily on the refusal of one of the sides' wife to join her husband to the East. R. Nissim ruled that it would be impermissible to force her to leave Perpignan, where this couple lived, to finis terrae. R. Nissim reported that he considered the well-being of the wife as an important reason, which could justify the abolition of an oath. Such a consideration would likely have been made before I348, when Perpignan was a flourishing city; by I348, the city has been plagued by the Black Death. ${ }^{55}$ Afterwards, it seems unlikely that he would have ruled that the quality of life in a city hit by a plague was better than in the remote Holy Land or on the way there. Therefore, this response indicates that even if Chelo's book is a forgery, rabbis of French origin lived in Jerusalem during the fourteenth century's first half.

Presumably, rabbis of a nascent community, like fourteenth-century Jerusalem, would have reflected the cultural background of their original communities. The indigenous Jewish communities in the Holy Land were almost annihilated during the Crusader period. There was no chance to create a Jewish community in Jerusalem that was based on the poor survivors of the Jewish communities of Jerusalem and its environs, which were destroyed during the Crusader period. The various origins of Jerusalem's rabbis indicate that the community was, as described by Chelo, from all over the Jewish world. Since pilgrimage and migration were extremely difficult, the possibility that Jews migrated from the Frankish cities to inland cities, before and after the conquest of Acre and Tyre, seems plausible. Nevertheless, people

\footnotetext{
${ }^{51} \mathrm{~F}$. Khull, Zweier deutscher Ordensleute pilgerfahrten nach Jerusalem in den Jahren 1333 und 1346 (Graz, I895), p. 35.

${ }^{52} \mathrm{R}$. Röhricht, "Le pèlerinage du moine augustin Jacques de Vérone", Revue de l'Orient Latin, III (I895), p. 224 .

${ }^{53}$ Carmoly, Itinéraires, pp. $239-240$.

${ }^{54}$ L. A. Feldman (ed.), Teshuvot HaRaN, [in Hebrew] (Jerusalem, I984), pp. I56-I63.

${ }^{55}$ R. W. Emery, "The Black Death of I 348 in Perpignan", Speculum, XLII (I967), pp. 6I I-623.
} 
of European origin who lived in Jerusalem and Safed from the I330s onward must have been very young, perhaps even children, in I29I. Such people were probably born in inland cities shortly before or after I29I or arrived there during the years that followed the destruction of the coastal cities.

\section{Conclusion}

Safed and Jerusalem, two of the major urban nuclei of the Mamluk Holy Land, ${ }^{56}$ had Jewish communities that were established during the late thirteenth and early fourteenth centuries. Safed replaced Tiberias as the central settlement in the Galilee and Safed's Jewish community replaced Tiberias's as the central Jewish community of the Galilee region. Presumably, the increasing importance of the city and its Jewish community attracted Jews who lived in the Frankish Acre and Tyre. This assumption is corroborated by documentation which refers to Jews from different Western-European origins who lived in Safed during the early fourteenth century. Since Jews of these origins were not documented in Safed prior to the fourteenth century, and taking into account the great difficulty in migrating after the fall of the Latin Kingdom of Jerusalem, I suggest that some Jews who left Acre before the city fell in I29I, or survived the massacre, did not return to Europe but moved to Safed. Tyre surrendered peacefully, and therefore the possibility that Jews from Tyre moved to Safed seems plausible.

Jerusalem did not have a Jewish community when it was occupied by the Mamluks. The Jewish community that emerged in Jerusalem during the early fourteenth century also included rabbis of Ashkenazi and French origin. I suggest that the Jewish communities of Safed and Jerusalem, and perhaps also of Gaza in the beginning of the fourteenth century, included a significant percentage of Jews of Western-European origin. Some of these Jews arrived directly to Jerusalem and Safed, before the collapse of the Latin Kingdom of Jerusalem, whereas others were survivors who managed to escape from Acre after the city was conquered by the Mamluks, and from Tyre following the city's capitulation to the Mamluks.

Michael Ehrlich

Bar-Ilan University, Ramat-Gan, Israel michael.ehrlich@biu.ac.il

\footnotetext{
${ }^{56}$ N. Luz, The Mamluk City in the Middle East (New York, 20I4), pp. 25-36.
} 